\title{
Virulence profile of different phylogenetic groups of locally isolated community acquired uropathogenic E. coli from Faisalabad region of Pakistan
}

Saira Bashir, Abdul Haque, Yasra Sarwar, Aamir Ali and Muhammad Irfan Anwar

\begin{abstract}
Background: Uropathogenic E.coli (UPEC) are among major pathogens causing urinary tract infections. Virulence factors are mainly responsible for the severity of these emerging infections. This study was planned to investigate the distribution of virulence genes and cytotoxic effects of UPEC isolates with reference to phylogenetic groups (B2, $B 1, D$ and $A$ ) to understand the presence and impact of virulence factors in the severity of infection in Faisalabad region of Pakistan.
\end{abstract}

Methods: In this study phylogenetic analysis, virulence gene identification and cytotoxicity of 59 uropathogenic $E$. coli isolates obtained from non-hospitalized patients was studied.

Results: Among 59 isolates, phylogenetic group B2 (50\%) was most dominant followed by groups A, B1 (19\% each) and $D(12 \%)$. Isolates present in group D showed highest presence of virulence genes. The prevalence hlyA (37\%) was highest followed by sfaDE (27\%), papC (24\%), cnf1 (20\%), eaeA (19\%) and afaBC3 (14\%). Highly hemolytic and highly verotoxic isolates mainly belonged to group $D$ and $B 2$. We also found two isolates with simultaneous presence of three fimbrial adhesin genes present on pap, afa, and sfa operons. This has not been reported before and underlines the dynamic nature of these UPEC isolates.

Conclusions: It was concluded that in local UPEC isolates from non-hospitalized patients, group B2 was more prevalent. However, group D isolates were most versatile as all were equipped with virulence genes and showed highest level of cytotoxicity.

Keywords: Uropathogenic E.coli, Phylogenicity, Virulence genes

\section{Background}

Uropathogenic E. coli (UPEC) are among the major pathogens causing urinary tract infections (UTIs). Phylogenetic studies have revealed that these bacteria are not of very diverse origin and fall into four main groups (A, $\mathrm{B} 1, \mathrm{~B} 2$, and D) $[1,2]$ nowadays. Phylogenetic analysis is usually done by targeting three genetic markers chuA, $y j a A$ genes and DNA fragment TSPE4.C2 [2]. This method has been found satisfactory and endorsed by other workers [3].

\footnotetext{
* Correspondence: sairabashir@gmail.com

* Correspondence: sairabashir@gmail.com
National Institute for Biotechnology and Genetic Engineering (NIBGE), P.O. Box 577, Jhang Road, Faisalabad, Pakistan
}

(c) 2012 Bashir et al.; licensee BioMed Central Ltd. This is an Open Access article distributed under the terms of the Creative Commons Attribution License (http://creativecommons.org/licenses/by/2.0), which permits unrestricted use, distribution, and reproduction in any medium, provided the original work is properly cited.

Virulent strains of $E$. coli mainly belong to phylogenetic groups B2 and D, while less virulent and commensal strains belong to phylogenetic groups B1 and A [2-7]. UPEC typically attach to epithelial cells with A-fimbrial adhesins ( $a f a)$, P-fimbrial adhesins ( $p a p)$, and S-fimbrial adhesins (sfa) [8-11]. Intimin, an attachment and membrane damaging pathogenicity factor, plays a vital role in virulence [12]. These virulence factors help bacteria to attach the epithelial cell lining of urinary tract and causes infection.

Hemolytic and cytotoxic necrotizing factors are also important virulence factors. The cnf1 is produced by $40 \%$ of uropathogenic E. coli isolates [13]. Most bacterial toxins cause initial cytopathic effects but only cytotoxins 
like cnf can lead to death of cultured cells [14]. In vitro alpha hemolysins and cytotoxic necrotizing factors have cytotoxicity towards different cells including Chinese hamster ovary, Vero and HeLa monolayers [15,16].

UTIs are very common in Pakistan and UPEC are the most frequent pathogens. Although a number of studies on this subject have been carried in various parts of the world, such data is not available from Pakistan. We felt that there was a need to characterize the local isolates of UPEC especially because no reports are currently available from this region.

\section{Materials and methods}

\section{Collection, identification and storage of UPEC}

Urine samples from non-hospitalized suspected cases of urinary tract infections were collected from various clinical laboratories of Faisalabad region. For isolation of E. coli, these samples were directly inoculated on MacConkey agar (Merck, Germany) plates. After overnight incubation at $37^{\circ} \mathrm{C}$, lactose-fermenting colonies were identified as $E$. coli by characteristic morphology and inoculation on Triple Sugar Iron (TSI) agar (Merck, Germany) slants. The isolates were kept as stocks at $-20^{\circ} \mathrm{C}$ in $50 \%$ glycerol stocks for long term storage.

\section{DNA Extraction and PCR based confirmation of $E$. coli isolates}

Each isolate was inoculated in $5 \mathrm{ml}$ of Tripticase Soy Broth (TSB). After overnight incubation at $37^{\circ} \mathrm{C}$, DNA was extracted by conventional phenol chloroform method and quantified according to Sambrook et al. [17]. For confirmation of E. coli, PCR was performed by targeting uidA gene by following conditions described by Heninger et al. [18]. Primers are listed in Table 1.

\section{Phylogenetic analysis}

A triplex PCR was performed to segregate each isolate into one of the four main phylogenetic groups (A, B1, $\mathrm{B} 2$ and $\mathrm{D})$ by targeting two marker genes (chuA and yjaA) and a DNA fragment TSPE4.C2 [2]. PCR conditions were same as described by Clermont et al. [2]. Primers are listed in Table 1.

\section{Targeted virulence related genes}

There are many virulence genes associated with UPEC. We selected six most reported virulence genes. Among toxin encoding genes, $h l y A$ gene was targeted for hemolysin and $c h f 1$ gene [19] for cytotoxic necrotizing factor. $\mathrm{S}$-fimbrial adhesin is specific for terminal sialyl galactoside residues present on human erythrocytes; $s f a D E$ gene [20] which is located on S-fimbrial gene cluster and is responsible for transport and assembling of fimbrial subunit was included, as well as papC gene [20] that is responsible for pyelonephritis associated adhesion, and $a f a B C 3$ gene [20] that is located on afa3 operon and is responsible for A-fimbrial adhesins. Yet another adhesin, intimin (encoded by eaeA gene) which has special significance in $E$. coli pathogenicity, was also included [21,22,23].

\section{Multiplex PCR for virulence related genes}

Multiplex PCR was performed for each isolate for the identification of virulence related genes. Each $100 \mu \mathrm{L}$ multiplex PCR reaction mixture contained 1X PCR buffer (50 mM KCl, $10 \mathrm{mM}$ Tris $\mathrm{HCl}$; pH 8.3), $2.5 \mathrm{mM}$ $\mathrm{MgCl}_{2}, 100 \mathrm{nmol}$ of each dNTP's, $100 \mathrm{pmol}$ of each primer, $5 \mathrm{U}$ of recombinant Taq polymerase, (Fermentas, USA) and $2 \mu \mathrm{L}$ of DNA template. Primers are listed in Table 1. The thermal cycler (MasterCycler; Eppondorf, Hamburg, Germany) conditions were as follows: $94^{\circ} \mathrm{C}$ for $5 \mathrm{~min}$ followed by 30 cycles of $94^{\circ} \mathrm{C}$ for $1 \mathrm{~min}, 56^{\circ} \mathrm{C}$ for $1 \mathrm{~min}$ and $72^{\circ} \mathrm{C}$ for $1 \mathrm{~min}$ and final extension of $5 \mathrm{~min}$ at $72^{\circ} \mathrm{C}$. The PCR products were separated by electrophoresis on $2 \%(\mathrm{w} / \mathrm{v})$ agarose gel and photographed by using Eagle Eye (Strategene, USA).

\section{Restriction analysis of virulence genes}

PCR products of the virulence genes were subjected to restriction analysis for confirmation. The sequences of the genes were taken from NCBI GenBank using primer base sequences. The accession numbers of the genes are as follows: papC (Y00529), sfaDE (X16664), afaBC3

Table 1 Oligonucleotide primers

\begin{tabular}{|c|c|c|c|}
\hline Genes & Primer sequences $\left(5^{\prime}\right.$ to $\left.3^{\prime}\right)$ & $\begin{array}{l}\text { Amplicon } \\
\text { size (bp) }\end{array}$ & References \\
\hline \multirow[t]{2}{*}{ chuA } & GACGAACCAACGGTCAGGAT & 279 & [2] \\
\hline & TGCCGCCAGTACCAAAGACA & & \\
\hline \multirow[t]{2}{*}{ yjaA } & TGAAGTGTCAGGAGACGCTG & 211 & [2] \\
\hline & ATGGAGAATGCGTTCCTCAAC & & \\
\hline \multirow[t]{2}{*}{ TspE4.C2 } & GAGTAATGTCGGGGCATTCA & 152 & [2] \\
\hline & CGCGCCAACAAAGTATTACG & & \\
\hline \multirow[t]{2}{*}{ uidA } & ATCACCGTGGTGACGCATGTCGC & 486 & [18] \\
\hline & CACCACGATGCCAT GTTCATCTGC & & \\
\hline \multirow[t]{2}{*}{ cnf1 } & GGCGACAAATGCAGTATTGCTTGG & 552 & [19] \\
\hline & GACGTTGGTTGCGGTAATTTTGGG & & \\
\hline \multirow[t]{2}{*}{ papC } & GACGGCTGTACTGCAGGGTGTGGCG & 328 & [20] \\
\hline & ATATCCTITCTGCAGGGATGCAATA & & \\
\hline \multirow[t]{2}{*}{$s f a D E$} & CTCCGGAGAACTGGGTGCATCTTAC & 408 & [20] \\
\hline & CGGAGGAGTAATTACAAACCTGGCA & & \\
\hline \multirow[t]{2}{*}{$a f a B C 3$} & CATCAAGCTGTTTGTTCGTCCGCCG & 793 & [20] \\
\hline & GCTGGGCAGCAAACTGATAACTCTC & & \\
\hline \multirow[t]{2}{*}{ eaeA } & GACCCGGCACAAGCATAAGC & 384 & [21] \\
\hline & CCACCTGCAGCAACAAGAGG & & \\
\hline
\end{tabular}


(X76688), hlyA (AB032930), eaeA (AF043226), chf1 (U42629). These genes were restricted with HaeIII, Hinf1, Pst1, EcoR1 and Tail enzymes respectively. Restriction conditions were similar in all cases. Each $30 \mu \mathrm{L}$ reaction mixture contained $1 \mu \mathrm{L}$ of restriction enzyme, 8 $\mu \mathrm{L}$ of PCR product, $3 \mu \mathrm{L}$ of specific enzyme buffer and $18 \mu \mathrm{L}$ of sterilized $\mathrm{dH}_{2} \mathrm{O}$. Overnight incubation was done at $37^{\circ} \mathrm{C}$ and the restriction products were separated on $2 \%$ agarose gel.

\section{Hemolysis assays}

Hemolysin $(h l y A)$ gene positive isolates were selected for studying hemolytic activity by using the method described by Haque et al. [24] with modifications. Human erythrocytes were used instead of rabbit erythrocytes and filtered supernatant of overnight culture of UPEC was double diluted with $0.9 \% \mathrm{NaCl}$ in a 96 well microdilution plate. Rest of the procedure was as previously reported. Hemolytic unit was calculated by plotting dilution factor against transmittance. One hemolytic unit is the dose of hemolysin that causes $50 \%$ hemolysis.

\section{Vero cell lines and Toxicity assay}

The cytotoxic effects of UPEC toxins (cytotoxic necrotizing factor and hemolysin) were studied by invading Vero cells. The Vero cell lines were grown in DMEM (MP Biomedical, USA), fetal calf serum 5-10\%, gentamicin $(1 \mu \mathrm{L} / \mathrm{mL})$ and amphotericin $(10 \mu \mathrm{L} / \mathrm{mL})$ in sterilized Petri plates and incubated overnight at $37^{\circ} \mathrm{C}$ in the presence of $5 \% \mathrm{CO}_{2}$. DMEM was removed from Vero cell plates followed by washing with PBS. Filtered and sterilized $(0.2 \mu \mathrm{m}$ pore size syringe filter) UPEC culture supernatant $(1.5 \mathrm{~mL})$ was added to each plate along with $1.5 \mathrm{~mL}$ DMEM and incubated overnight at $37^{\circ} \mathrm{C}$ with $5 \%$ $\mathrm{CO}_{2}$. The medium was removed from Petri plates into the falcon tubes. One $\mathrm{mL}$ of $1 \mathrm{X}$ trypsin: EDTA solution was added and after $5 \mathrm{~min}$, dislodged cells were transferred to the same falcon tube. The falcon tube was centrifuged at 10,000 rpm for 10 minutes and supernatant was discarded; $1 \mathrm{~mL}$ of trypan blue was added, mixed gently and incubated at $37^{\circ} \mathrm{C}$ for $10 \mathrm{~min}$. The ratio of dead (stained) and living cells was counted in a hemocytometer using inverted microscope $(x 4)$. The concentration resulting in 50\% stained cells represented the $50 \%$ cytotoxic dose.

\section{Statistical analysis}

Analysis of variance was used to compare the prevalence of various phylogenetic groups and presence of different virulence related genes. The difference having $P$ value equal or less than 0.05 was considered as statistically significant.

\section{Results}

\section{Confirmation of $E$. coli isolates}

A total of 59 isolates were confirmed as $E$. coli by conventional biochemical identification followed by the detection of uidA gene.

\section{Phylogenetic analysis}

Out of 59 UPEC isolates, the group B2 isolates 30 (50\%) were found significantly higher $(P<0.05)$ as compared to other phylogenetic groups. Seven (12\%) isolates fell in group D and 11 (19\%) belonged to each of groups A and B1. Groups B1 and B2 showed two different patterns each. Details are given in Table 2.

\section{Prevalence of virulence genes among UPEC isolates}

The targeted virulence genes were detected in $37(63 \%)$ isolates. Remaining isolates were negative for the targeted genes. All the 7 group D isolates showed presence of these virulence genes. Breakup for other groups was: A 5/11 (45\%), B1 6/11 (55\%), and B2 18/30 (60\%).

It was found that most prevalent gene was hly $A$ which was detected in 22 isolates (37\%) while 16 (27\%), 14 (24\%), $11(19 \%), 12(20 \%)$, and 8 (14\%) isolates were positive for $s f a D E$, papC, eaeA, cnf1, and $a f a B C 3$ genes respectively. One isolate was positive for all 6 targeted virulence genes, two showed presence of 5 genes, and in three others 4 genes were detected. Three, two and one genes were found in 7, 10 and 14 isolates respectively. Detailed results are shown in Table 3.

It was also found that papC, chf1 and hlyA were present collectively in 4 isolates, where as papC, $s f a D E$ and $a f a B C 3$ genes which represent P-fimbial, S-fimbrial and A-fimbrial adhesins respectively, were also identified collectively in two isolates as shown in the Table 4.

The detected genes were confirmed by restriction analysis: $s f a D E$ and $p a p C$ amplicons (410 and 328 bp respectively) were restricted with HaeIII and yielded fragments of 209 bp, 135 bp and 66 bp; and 161 bp, 112 bp and 55 bp respectively. The afaBC3 amplicon (793 bp) was restricted with Hinf1 and yielded fragments of 565 and $228 \mathrm{bp}$. The eaeA amplicon (384 bp) was restricted with EcoR1 and

Table 2 Phylogenetic distribution of uropathogenic E. coli

\begin{tabular}{lccccc}
\hline $\begin{array}{l}\text { Phylogenetic } \\
\text { groups }\end{array}$ & $\begin{array}{c}\text { No. of } \\
\text { UPEC } \\
\text { isolate } \\
\mathbf{n = 5 9}\end{array}$ & $\begin{array}{c}\text { Distribution } \\
\text { according } \\
\text { to gene } \\
\text { groupings (n) }\end{array}$ & $\begin{array}{c}\text { chuA } \\
\text { gene }\end{array}$ & $\begin{array}{c}\text { yjaA } \\
\text { gene }\end{array}$ & TSPE4.C2 \\
\hline Group B2 & $30(50 \%)$ & 28 & + & + & + \\
Group B1 & $11(19 \%)$ & 02 & + & + & - \\
& & 02 & - & - & + \\
Group A & $11(19 \%)$ & 11 & - & + & + \\
Group D & $07(12 \%)$ & 07 & + & + & - \\
\hline
\end{tabular}


Table 3 Prevalence of virulence related genes in various phylogenetic groups of uropathogenic $E$. coli isolates

\begin{tabular}{|c|c|c|c|c|c|c|c|}
\hline \multirow[t]{2}{*}{ Phylogenetic groups } & \multirow{2}{*}{$\begin{array}{l}\text { No. of Isolates with } \\
\text { Virulence genes }\end{array}$} & \multicolumn{6}{|c|}{ Distribution of virulence genes } \\
\hline & & papC & sfaDE & $a f a B C 3$ & eaeA & hlyA & cnf1 \\
\hline Group B2 & $18 / 30(60 \%)$ & 10 & 08 & 04 & 05 & 11 & 05 \\
\hline Group B1 & 07/11 (64\%) & 02 & 03 & 01 & 01 & 02 & 03 \\
\hline Group A & 05/11 (45\%) & 0 & 0 & 01 & 02 & 04 & 01 \\
\hline Group D & 07/07 (100\%) & 02 & 05 & 02 & 030503 & & \\
\hline Total & $37 / 59(63 \%)$ & 14 & 16 & 08 & 11 & 22 & 12 \\
\hline
\end{tabular}

yielded fragments of 305 and 79 bp. Tail and msp1 were used to restrict amplicons of chf1 (552 bp) and hlyA (534 bp) genes respectively to yield fragments of 356, 192 and $4 \mathrm{bp}$, and 315 and $219 \mathrm{bp}$.

\section{Phylogenicity and virulence}

When relationship of phylogenicity and virulence was studied, the prevalence of all virulence genes was found significantly higher in phylogenetic group $\mathrm{D}(P<0.05)$ as compared to other phylogenetic groups except for papC gene which was found highest in group B2 isolates. The

Table 4 Presence of virulence genes in UPEC isolates

\begin{tabular}{|c|c|c|}
\hline $\begin{array}{l}\text { No. of } \\
\text { Genes }\end{array}$ & Virulence Genes & $\begin{array}{c}\text { No. of Isolates } \\
(n=59)\end{array}$ \\
\hline 6 & sfaDE, afaBC3, papC, eaeA, cnfl, hlyA & 1 \\
\hline 5 & sfaDE, papC, eaeA, cnfl, hlyA & 1 \\
\hline 5 & sfaDE, afaBC3, papC, cnf1, hlyA & 1 \\
\hline 4 & sfaDE, papC, eaeA, hlyA & 2 \\
\hline 4 & afaBC3, papC, eaeA, hlyA & 1 \\
\hline 3 & sfaDE, cnfl, hlyA & 3 \\
\hline 3 & papc, eaeA, hlyA & 1 \\
\hline 3 & afaBC3, eaeA, hlyA & 1 \\
\hline 3 & $a f a B C 3, p a p C$, hlyA & 1 \\
\hline 3 & papC, cnfl, hlyA & 1 \\
\hline 2 & eaeA, hlyA & 3 \\
\hline 2 & sfaDE, cnf1 & 1 \\
\hline 2 & sfaDE, hlyA & 3 \\
\hline 2 & sfaDE,papC & 2 \\
\hline 2 & papC,hlyA & 1 \\
\hline 1 & $s f a D E$ & 2 \\
\hline 1 & $a f a B C 3$ & 3 \\
\hline 1 & papc & 2 \\
\hline 1 & eaeA & 1 \\
\hline 1 & cnf1 & 4 \\
\hline 1 & hlyA & 2 \\
\hline 0 & No gene & 22 \\
\hline
\end{tabular}

Note: $s f a D E$, S-fimbrial adhesin; $\boldsymbol{a f a B C 3}$, A-fimbrial adhesin; papC, P-fimbrial adhesin; eaeA, Intimin; $\boldsymbol{c n f 1}$, cytotoxic necrotizing factor; hlyA, hemolysin.
papC and $s f a D E$ genes were absent in all group A isolates (Table 3).

\section{Hemolysis assay}

Out of 59 isolates, 22 isolates were $h l y A$ positive. All hlyA positive isolates (22) showed hemolytic activity in hemolysis assay. Hemolytic activity was classified into three groups, highly hemolytic (above $20 \mathrm{HU}$ ), moderately hemolytic (between 10-20 HU) and poorly hemolytic (below $10 \mathrm{HU}$ ). Accordingly, among 22 isolates, $3(14 \%)$ were found highly hemolytic, $3(14 \%)$ as moderately hemolytic and $16(72 \%)$ as poorly hemolytic.

\section{Verotoxicity assay}

Twenty seven isolates which were positive for $h l y A$ and/ or $\operatorname{cnf1}$ genes were selected for verotoxicity assay. Among 27 isolates, 15 were $h l y A$ positive, 5 were $c n f 1$ positive and 7 possessed both genes. All the isolates showed verotoxicity. They were classified into highly toxic (80-100\% cell death), moderately toxic (50-80\%) and poorly toxic (below 50\%). More details are given in Table 5.

\section{Discussion}

UPEC are major cause of urinary tract infections and may be responsible for nearly $90 \%$ of UTI [25]. There are four main phylogenetic groups (A, B1, B2, and D) of UPEC and the phylogenicity has been reported to play an important role in virulence of these pathogens [1-3]. Although a number of studies on this subject have been carried in various parts of the world, such data is not available from Pakistan where UTI are very common. This study was designed to characterize local isolates of UPEC with respect to phylogenicity and distribution of most important virulence factors. Although our study is comprised of a relatively small number of samples and therefore faces limitations in statistical analysis, it provides important information about the phylogenetic background of uropathogenic E.coli from this region.

In the present study, we found that $50 \%$ of our isolates belonged to a single phylogenetic group B2 which is in line with some other studies [4,5]. 
Table 5 Verotoxicity assay of $h l y A$ and $c n f 1$ gene positive UPEC isolates $(n=27)$

\begin{tabular}{lccc}
\hline & hlyA gene positive isolates $(\mathbf{n = 1 5})$ & $\mathbf{c n f 1}$ gene positive isolates $(\mathbf{n}=\mathbf{5})$ & $\boldsymbol{h} \mathbf{l y} \boldsymbol{A}+\boldsymbol{c n f 1}$ positive isolates $(\mathbf{n}=\mathbf{7})$ \\
\hline Highly toxic & 06 & 01 & 04 \\
$80-100 \%$ cell death & 05 & 03 & 01 \\
$\begin{array}{l}\text { Moderately toxic } \\
\text { 50-80\% cell death }\end{array}$ & 04 & 01 & 02 \\
Poorly Toxic & & & \\
Below 50\% cell death & & & \\
\hline
\end{tabular}

We found that among all phylogenetic groups, most of the virulence related genes were present in significantly higher proportion in phylogenetic group D isolates except papC gene, which was more frequent in $\mathrm{B} 2$ isolates. This is in accordance with the report of Nowrouzian et al. [26] who found that most B2 strains carried genes for P-fimbriae.

Our results also supported some previous reports indicating greater association of traditionally recognized uropathogenic virulence factors (e.g. pap, sfa, and $h l y$ ) with groups D and B2 as compared with $\mathrm{A}$ and $\mathrm{B} 1[6,27]$.

Among adhesins, $s f a D E$ was highly (27\%) prevalent among local UPEC isolates followed by papC (24\%) and $a f a B C 3(8 \%)$ genes. We found that frequency of $s f a$ was higher as compared to other genes. In some of isolates, multiple adhesin genes were identified (pap and $s f a$; pap and afa; pap, sfa and afa) where as in some other isolates these genes were present independently. Here again, phylogenetic group D was most prominent. Our findings are comparable with those of Le Bouguenec et al. [20] who found pap operon in $79.4 \%$ of the pyelonephritis strains, either present alone $(51.5 \%)$ or in association with either afa or $s f a$ operon (27.9\%), whereas in $12.4 \%$ and $22.7 \%$ of the isolates the adhesive properties were associated with the presence of afa and $s f a$ operons, respectively. It is important to note that we did find these three operons in two isolates. The simultaneous presence of pap, afa, and sfa operons has not been reported before.

The intimin adhesin (eaeA gene) is an attachment and membrane damaging pathogenicity factor. It was found in 19\% of the isolates. The presence of this adhesin gene has also been previously reported in UPEC [23] though it is well known that it is associated with diarrhoeagenic E. coli $[21,28]$.

Among toxins, hemolysin was identified in 22 (37\%) isolates. These findings are in line with those of BingenBidois et al. [29] who found hly gene in 34\% of UPEC isolates. In the present study, all $h l y A$ gene positive isolates hemolysed human erythrocytes.

Our UPEC isolates showed considerable cytotoxic effects and 20\% were positive for cnfl gene. When 27 (46\%) UPEC isolates having cnfl, hlyA or both genes were used to invade the Vero cells, highest toxicity (80-
$100 \%$ vero cell death) was observed in hlyA gene positive isolates $(\mathrm{n}=06)$, followed by hlyA $\operatorname{cnf1}(\mathrm{n}=04)$ and cnf1 positive $(\mathrm{n}=01)$ isolates. This is in agreement with the reports suggesting that during the early stages of uropathogenesis, hly plays a major role in the damage of uroepithelium. It has also been reported that in many uropathogenic E. coli the loci of hly and cnfl are often linked and responsible for the severity of urinary tract infections [30].

High cytotoxicity levels were not always found associated with chf1 and hly positive isolates in this study because some isolates which were positive for other virulence genes, showed cytotoxic effect as well. On the other hand, some isolates with cnfl did not express any cytotoxic effect on Vero cells. It may be due to an insertion of a thymidine base at position 3325 in the C-terminal domain of cnfl, which encodes the catalytic region of the toxin $[31,32]$. The cumulative presence of $p a p C, \operatorname{cnf} 1$ and $h l y A$ is the evidence of pathogenicty island $\mathrm{II}_{\mathrm{J} 96}$, which is highly prevalent among UTI isolates [33]. In the present study the simultaneous presence of papC, chfl and hlyA was observed in 4 UPEC isolates.

Highly hemolytic isolates belonged to phylogenetic group $\mathrm{D}$, while highly cytotoxic isolates belonged to group B2 and D. This is in partial disagreement with the studies of Zhang et al. [34] who found that hly and cnf1 positive isolates mainly belonged to phylogenetic group B2.

It can be concluded that all local UPEC isolates have a battery of virulence factors which makes them a serious and challenging health problem. The simultaneous presence of pap, afa, and $s f a$ operons has been reported for the first time underlining the dynamic nature of these isolates. Another finding of interest was the prominence of Group D in relevance to the presence of virulence factors. The previous reports from other parts of the globe mostly highlight Group B2.

\section{Competing interests}

All authors declare that they have no competing interest.

Authors' contributions

SB carried out sample collection, analysis and drafted the manuscript, $\mathrm{AH}$ provided concept and finally drafted the manuscript, YS and AA provided guidance in Lab work, MIA helped in sample collection and preparation of manuscript. All authors read and approved the final manuscript. 


\section{Acknowledgments}

This work was carried out by the facilities and funding provided by National Institute for Biotechnology and Genetic Engineering (NIBGE), Faisalabad, Pakistan.

Received: 9 May 2012 Accepted: 22 July 2012 Published: 6 August 2012

\section{References}

1. Herzer PJ, Inouye S, Inouye M, Whittam TS: Phylogenetic distribution of branched RNA-linked multicopy single-stranded DNA among natural isolates of Escherichia coli. J Bacteriol 1990, 172:6175-6181.

2. Clermont O, Bonacorsi S, Bingen E: Rapid and simple determination of the Escherichia coli phylogenetic groups. App/ Environ Microbio/ 2000, 66:4555-4558

3. Gordon DM, Clermont O, Tolley H, Denamur E: Assigning Escherichia coli strains to phylogenetic groups: multi-locus sequence typing versus the PCR triplex method. Environ Microbiol 2000, 10:2484-2496.

4. Johnson JR, Stell AL: Extended virulence genotypes of Escherichia coli strains from patients with urosepsis in relation to phylogeny and host compromise. J Infect Dis 2000, 181:261-272.

5. Picard B, Garcia JS, Gouriou S, Duriez P, Brahimi N, Bingen E: The link between phylogeny and virulence in Escherichia coli extraintestinal infection. Infect Immun 2000, 67:546-553.

6. Boyd EF, Hartl DL: Chromosomal regions specific to pathogenic isolates of Escherichia coli have a phylogeneticaly clustered distribution. J Bacteriol 1998, 180:1159-1165.

7. Johnson JR, van der Schee C, Kuskowski MA, Goessens W, Belkum AV: Phylogenetic background and virulence profiles of fluoroquinoloneresistant clinical Escherichia coli isolates from Netherlands. J Infect Dis 2002, 186:1852-1856.

8. Le Bouguenec C, Garcia MI, Ouin V, Desperrier JM, Gounon P, Labigne A: Characterization of plasmid borne afa-3 gene clusters encoding afimbrial adhesins expressed by Escherichia coli strains associated with intestinal or urinary tract infections. Infect Immun 1993, 61:5106-5114.

9. Garcia MI, Labigne A, Le Bouguenec C: Nucleotide sequence of the afimbrial-adhesin-encoding afa-3 gene cluster and its translocation via flanking IS1 insertion sequences. J Bacteriol 1994, 176:7601-7613.

10. Dobrindt U, Blum-Oehler G, Hartsch T, Gottschalk G, Ron EZ, Funfstuck R: S-Fimbrial encoding determinant $s f(I)$ is located on pathogenicity island III (536) of uropathogenic Escherichia coli strain 536. Infect Immun 2001, 69:4248-4256

11. Wang Y, Wen ZG, Kim KS: Role of S fimbriae in Escherichia coli K1 binding to brain microvascular endothelial cells in vitro and penetration into the central nervous system in vivo. Microb Pathog 2004, 37:287-293.

12. Lacher DW, Steinsland H, Whittam TS: Allelic subtyping of the intimin locus (eae) of pathogenic Escherichia coli by fluorescent RFLP. FEMS Microbiol Lett 2006, 261:80-87.

13. Hofman P, Le Negrate G, Mograbi B, Hofman V, Brest P, Alliana-Schmid A: Escherichia coli cytotoxic necrotizing factor-1 (CNF-1) increases the adherence to epithelia and the oxidative burst of human polymorphonuclear leukocytes but decreases bacteria phagocytosis. J Leuko Biol 2000, 68:522-528.

14. Thelestam M, Florin I: Assay of cytopathogenic toxins in cultured cells. Methods Enzymol 1994, 235:679-690.

15. Ghadir S, El-Housseiny, Aboulwafa MM, Hassouna NA: Cytotoxic activities of some Escherichia coli isolates: Possible mechanisms and approaches for inhibition. J American Sci 2010, 6:269-283.

16. Caprioli A, Falbo V, Roda LG, Ruggeri FM, Zona C: Partial purification and characterization of an Escherichia coli toxic factor that induces morphological cell alterations. Infect Immun 1983, 39:1300-1306.

17. Sambrook J, Fritsch EF, Maniatis T: Molecular Cloning: a laboratory manual. 2nd edition. USA: Cold Spring Harbor Laboratory Press; 1989.

18. Heninger A, Binder M, Schmidt S, Unertl K, Botzenhart K, Doring G: PCR and blood culture of Escherichia coli bacteremia in rats. Antimicrob $\mathrm{Ag}$ Chem 1999, 37:2479-2482.

19. Pass MA, Odedra R, Batt RM: Multiplex PCRs for identification of Escherichia coli virulence genes. J Clin Microbiol 2000, 38:2001-2004.

20. Le Bouguenec C, Archambaud M, Labigne A: Rapid and specific detection of the pap, afa, and sfa adhesin-encoding operons in uropathogenic
Escherichia coli strains by polymerase chain reaction. J Clin Microbiol 1992, 30:1189-1193.

21. Yu J, Kaper JB: Cloning and characterization of the eae gene of enterohaemorrhagic Escherichia coli O157:H7. Mol Microbiol 1992, 6:411-417

22. Paton AW, Paton JC: Detection and characterization of shiga toxigenic Escherichia coli by using multiplex PCR assays for stx1, stx2, eaeA, Enterohemorrhagic E.coli hlyA, rfbO111, and rfbO157. J Clin Microbiol 1998, 36:598-602.

23. Abe CM, Salvador FA, Falsetti IN, Vieira MAM, Blanco J, Blanco JE: Uropathogenic Escherichia coli (UPEC) strains may carry virulence properties of diarrhoeagenic E. coli. FEMS Immunol Med Microbiol 2008, 52:397-406.

24. Haque A, Sugimoto N, Horiguchi Y, Okabe T, Miyata T, Iwanagaal S: Production, purification and characterization of botulinolysin, a thiol activated hemolysin of Clostridium botulinum. Infect Immun 1992, 60:71-78.

25. Johnson JR, Russo TA: Extraintestinal pathogenic Escherichia coli: 'the other bad E coli'. J Lab Clin Med 2002, 39:155-162.

26. Nowrouzian FL, Adlerberth I, Wold AE: Enhanced persistence in the colonic microbiota of Escherichia coli strains belonging to phylogenetic group B2: role virulence factors and adherence to colonic cells. Microb Infect 2006, 8:834-840.

27. Johnson JR, Delavari P, Kuskowski M, Stell AL: Phylogenetic distribution of extraintestinal virulence associated traits in Escherichia coli. $J$ Infect Dis 2001, 183:78-88.

28. Elliot SJ, Wainwright LA, McDaniel TK, Jarvis KG, Deng YK, Lai LC: The complete sequence of the locus of enterocyte effacement (LEE) from enteropathogenic Escherichia coli E2348/69. Mol Microbiol 1998, 28:1-4.

29. Bingen-Bidois M, Clermont O, Bonacorsi S, Terki M, Brahimi N, Loukil C: Phylogenetic analysis and prevalence of urosepsis strains of Escherichia coli bearing pathogenicity island-like domains. Infect Immun 2002, 70:216-226.

30. Smith YC, Rasmussen SB, Grande KK, Conran RM, O'Brien DO: Hemolysin of uropathogenic Escherichia coli evokes extensive shedding of the uroepithelium and hemorrhage in bladder tissue within the first 24 hours after intraurethral inoculation of mice. Infect Immun 2008, 76:2978-2990.

31. Lemichez E, Flatau G, Bruzzone M, Boquet P, Gauthier M: Molecular localization of the Escherichia coli cytotoxic necrotizing factor CNF1 cellbinding and catalytic domains. Mol Microbiol 1997, 24:1061-1070.

32. Schmidt G, Selzer J, Lerm M, Aktories K: The Rho-deamidating cytotoxic necrotizing factor 1 from Escherichia coli possesses transglutaminase activity, cysteine 866 and histidine 881 are essential for enzyme activity. J Biol Chem 1998, 273:13669-133674.

33. Piatti G, Mannini A, Balistreri M, Schito AM: Virulence factors in urinary Escherichia coli strains: Phylogenetic background and quinolone and fluoroquinolone resistance. J Clin Microbiol 2008, 46:480-487.

34. Zhang WL, Kohler B, Oswald E, Beutin L, Karch H, Morabito S: Genetic diversity of intimin genes of attaching and affacing Escherichia coli strains. J Clin Microbiol 2002, 40:4486-4492.

doi:10.1186/1476-0711-11-23

Cite this article as: Bashir et al:: Virulence profile of different phylogenetic groups of locally isolated community acquired uropathogenic $E$. coli from Faisalabad region of Pakistan. Annals of Clinical Microbiology and Antimicrobials 2012 11:23. 